\title{
Abiotic environmental conditions for germination and development of gametophytes of Cyathea phalerata Mart. [Cyatheaceae)
}

\author{
Catiuscia Marcon', Tatieli Silveira², Jairo Lizandro Schmitt ${ }^{3}$ and Annette Droste ${ }^{1}$
}

Received: August 9, 2016

Accepted: January 23, 2017

\begin{abstract}
In order to successfully establish themselves in their natural environment, ferns need habitats with abiotic conditions that are suitable for spore germination and gametophyte development. The objective of this study was to assess the influence of abiotic factors on the initial development of Cyathea phalerata cultivated in vitro. Spore germination and gametophyte development were assessed under varying conditions of surface sterilization, $\mathrm{pH}$, temperature and photoperiod. Exogenous contamination was eliminated by sterilizing spores with $2.5 \% \mathrm{NaClO}$ for 15 min and sowing them into a culture medium supplemented with nystatin. Spores germinated at all pHs tested. Gametophytic development was faster in acidic $\mathrm{pHs}$. Cultures at $25^{\circ} \mathrm{C}$ exhibited the highest percentages of germination and laminar gametophytes. The species produced its highest percentages of gametophytes in cultures with photoperiods between 6 and $18 \mathrm{~h}$. The optimal abiotic conditions found here for in vitro development of $C$. phalerata are similar to those found in its natural habitat. The southern limit of this species to north of the 30th parallel in Rio Grande do Sul, Brazil, may be because further south spores do not encounter the ideal combined conditions of temperature, $\mathrm{pH}$ and photoperiod determined in the laboratory.
\end{abstract}

Keywords: abiotic factors, arborescent ferns, in vitro propagation, reproduction, spores

\section{Introduction}

For the sporophytes of ferns to settle in their natural environment, they need habitats and abiotic conditions that are suitable for the germination of spores and the development of gametophytes (Page 1979). The most important of such factors include temperature, photoperiod (Miller 1968; Ranal 1999; Esteves 2013) and the $\mathrm{pH}$ of the substrate (Petersen 1985). However, due to the difficulty of monitoring the initial development stages of ferns in their natural habitat, most studies have concentrated on understanding the sporophytic stage. In vitro culture provides an environment in which conditions are controlled, making it possible to evaluate the influence of abiotic factors on the germination of spores and the initial development, considering that the morphological structure of fern gametophytes appears to be highly conserved across in vitro and in situ environments (Farrar et al. 2008).

Arborescent ferns play an important role in tropical forests and, in particular, due to its long and erect caudices, they provide a habitat for many epiphytic species (Schmitt \& Windisch 2010; Schneider \& Schmitt 2011). However, these plants are targets of extractive exploitation, particularly in the South of Brazil, which has a negative impact on the

\footnotetext{
${ }^{1}$ Laboratório de Biotecnologia Vegetal, Programa de Pós-Graduação em Qualidade Ambiental, Universidade Feevale, 93525-075, Novo Hamburgo, RS, Brazil

${ }^{2}$ Laboratório de Biotecnologia Vegetal, Universidade Feevale, 93525-075, Novo Hamburgo, RS, Brazil

${ }^{3}$ Laboratório de Botânica, Programa de Pós-Graduação em Qualidade Ambiental, Universidade Feevale, 93525-075, Novo Hamburgo, RS, Brazil

* Corresponding author: annette@feevale.br
} 
availability of microhabitats for epiphytes that preferentially or exclusively occur on their caudices (Schmitt \& Windisch 2005).

Cyathea phalerata is an arborescent fern belonging to the Cyatheaceae for which there are records in Bolivia (Lehnert 2006) and in all regions of Brazil, in the phytogeographic domains of the Atlantic Forest and the Cerrado (Windisch \& Santiago 2015). As a result of the drastic reduction of the Atlantic Forest in the state of Rio Grande do Sul, C. phalerata is on the list of species threatened with extinction, in the critically endangered category (Rio Grande do Sul 2014). This plant preferentially grows in the shadowy interior of forests, both along water courses and in the interfluvial areas of humid forests, or close to streams in drier forests, but it can also be found in gallery forests and forest edge gullies, and at altitudes ranging from sea level up to 1,500 meters. C. phalerata plants develop caudices of up to 4 $\mathrm{m}$. Their leaves can be as long as $3.5 \mathrm{~m}$ and the petioles bear thorns measuring 2-8 $\mathrm{mm}$, which may be muricate or glabrous (Fernandes 2003). Popularly, the species is known as a medicinal plant, since the inner part of the caudices and leaves may be used in alcoholic extracts to fight inflammatory diseases (Hort et al. 2008).

There are no records about the influence of different abiotic factors in the germination of spores and the initial development of $C$. phalerata. Over the last ten years, studies have been concentrated on C. delgadii (Hiendlmayer \& Randi 2007), C. atrovirens (Azevedo et al. 2008; Rechenmacher et al. 2010; Silveira et al. 2013; Vargas \& Droste 2014; Marcon et al. 2015) and C. corcovadensis (Medeiros et al. 2016).

Although germination of fern spores in vitro has been shown to be effective (Dyer 1979), exogenous contamination is an obstacle to successful cultivation over the long term (Dyer 1979; Vargas \& Droste 2014). Only a small number of the antimicrobial agents that can be used to prevent in vitro contamination of plants have been tested with ferns, including nystatin (Dyer 1979; Simabukuro et al. 1998; Quintanilla et al. 2002; Vargas \& Droste 2014), streptomycin (Cox et al. 2003) and actidione (Vargas \& Droste 2014).

The aim of the study was to assess the influence of antimicrobial agents, temperature, photoperiod and $\mathrm{pH}$ on germination and development of $C$. phalerata gametophytes, and based on the results, determine the ideal abiotic conditions for the establishment of the initial stage in the life cycle of ferns in a controlled environment, and to relate them to the abiotic characteristics found in the natural habitat of the species.

\section{Materials and methods}

\section{Collection and processing of spores}

The donor plants of Cyathea phalerata Mart. from which fertile leaves were collected grow in the domain of the
Atlantic Forest, specifically in a riparian forest (29 $42^{\prime} 25.0^{\prime \prime}$; $50^{\circ} 17^{\prime} 27.8^{\prime \prime} \mathrm{W}$ ) located in the upper stretch of the Rio dos Sinos hydrographic basin, which is between the coastal and mountainous regions of the state of Rio Grande do Sul, Brazil. The vegetation is composed of elements characteristic of Dense and Mixed Rain Forest with canopy openness ranging from $10.4 \%$ to $18.6 \%$ (Rocha-Uriartt et al. 2015). The region's climate is type "Cfa" according to the Köppen classification (humid, subtropical) and is characterized by well-distributed rainfall throughout the year (Peel et al. 2007). At the site in which $C$. phalerata grows, the mean annual temperature ranges from 18.9 to $21.2^{\circ} \mathrm{C}$ and annual rainfall ranges from 2,406 to 2,706 $\mathrm{mm}$ (Rocha-Uriartt et al. 2015).

Fertile leaves were collected in March of 2014 and placed in trays in which they were kept at room temperature for 72 hours, for dehiscence of the sporangia. The spores were filtered through interleaved paper towels (Melpaper ${ }^{\circ}$ ) and stored in eppendorf tubes at a temperature of $7{ }^{\circ} \mathrm{C}$ (Rechenmacher et al. 2010).

\section{Establishment of ideal conditions for spore surface sterilization}

Experiment I: $30 \mathrm{mg}$ samples of $C$. phalerata spores were placed in $1.5 \mathrm{~mL}$ eppendorf tubes and subjected to surface sterilization with $1 \mathrm{~mL}$ of sodium hypochlorite solution $(\mathrm{NaClO})$ at concentrations of 1.5 and $2 \%$, for $15 \mathrm{~min}$. After removing this disinfectant agent, $1 \mathrm{~mL}$ of autoclaved distilled water was added to each tube to rinse the spores, and they were then centrifuged for $3 \mathrm{~min}$ at 3,000 $\mathrm{rpm}$. The washing and centrifuging stages were repeated four times.

In a horizontal laminar flow chamber, spores were sown in $200 \mathrm{~mL}$-glass flasks (10 mg/flask), containing $30 \mathrm{~mL}$ of Meyer liquid medium (Meyer et al. 1955), with $\mathrm{pH}$ adjusted to 5.0 prior to sterilization in autoclave, and then supplemented with one of the following antimicrobial agents: $50,000 \mathrm{U} \mathrm{mL}^{-1}$ of nystatin (Sigma-Aldrich) and $0.5 \mathrm{~g} \mathrm{~L}^{-1}$ of actidione (Fluka, Sigma-Aldrich), according to the methodology adapted from Vargas \& Droste (2014). Three repetitions were prepared for each combination of $\mathrm{NaClO}$ concentration (1.5 and $2 \%$ ) and antimicrobial agent (nystatin and actidione) totaling 12 flasks. The cultures were kept at $26 \pm 1^{\circ} \mathrm{C}$, with a photoperiod of $12 \mathrm{~h}$ of light and luminosity of $70 \mu \mathrm{mol} \mathrm{m}^{-2} \mathrm{~s}^{-1}$.

After 30 days of cultivation, a qualitative analysis was conducted to check for fungi and/or bacteria, and a quantitative analysis was conducted to assess spore germination and gametophytic development. A microscopy slide was prepared for each flask. The first 100 specimens viewed per slide with a binocular optical microscope (Nikon, Eclipse E200) at 400 times magnification were classified as germinated or not germinated spores. The criterion adopted to define germination was the emergence of a chlorocyte or 
rhizoid (Ranal 1999). Laminar and cordiform gametophytes, representing the two more advanced development stages, were identified according to Rechenmacher et al. (2010) and counted.

Experiment II: Eppendorf tubes were prepared with $100 \mathrm{mg}$ of $C$. phalerata spores that had undergone surface sterilization with different sodium hypochlorite concentrations and exposure times. These treatments were as follows: $2 \% \mathrm{NaClO}$ for $20 \mathrm{~min}, 2 \% \mathrm{NaClO}$ for $25 \mathrm{~min}$ and $2.5 \% \mathrm{NaClO}$ for $15 \mathrm{~min}$. The processes of washing and sowing the spores were as described for Experiment I, but for Experiment II, only the culture medium supplemented with $50,000 \mathrm{U} \mathrm{mL}^{-1}$ of nystatin was used. Ten repetitions were prepared for each $\mathrm{NaClO}$ concentration/surface sterilization time, totaling 30 flasks, which were then cultivated as described for Experiment I. Contamination, germination of spores and gametophytic development were assessed after 30 days of in vitro cultivation, following the methodology described for Experiment I.

\section{Assessment of the influence of abiotic conditions on spore germination and gametophyte development}

In order to assess germination of spores and gametophytic development in different $\mathrm{pH}$ conditions in vitro, culture media were tested at $\mathrm{pHs} 4,5,6$ and 7. Spores underwent surface sterilization with $2.5 \% \mathrm{NaClO}$ for 15 min, based on the results of Experiment II. Spores were sown in a horizontal laminar flow chamber, with $10 \mathrm{mg}$ samples distributed into $200 \mathrm{~mL}$-glass flasks containing $30 \mathrm{~mL}$ of Meyer liquid medium previously sterilized in an autoclave and supplemented with nystatin $\left(50,000 \mathrm{U} \mathrm{mL}^{-1}\right)$, based on the results of the surface sterilization experiments. For each $\mathrm{pH}$, three repetitions were prepared, totaling 12 flasks. These cultures were kept under controlled conditions and the ontogenetic development was analyzed at seven, 30 and 60 days of cultivation, using the same methodology described for Experiment I.

The influence of temperature on germination of spores and development of gametophytes was tested using the following treatments: 10, 15, 20, 25 and $30^{\circ} \mathrm{C}$. For this experiment, spores were subjected to surface sterilization with $2.5 \% \mathrm{NaClO}$ for $15 \mathrm{~min}$, sown in Meyer liquid medium supplemented with nystatin $\left(50,000 \mathrm{U} \mathrm{mL}^{-1}\right)$ and with $\mathrm{pH}$ adjusted to 5.0, based on the results of the previous experiment. Three repetitions were prepared for each temperature, totaling 15 flasks. These cultures were kept in a germination chamber under the same conditions of light intensity as those used for the previous experiment. Germination and gametophytic development were assessed after seven, 30 and 60 days of cultivation using the same methodology described for Experiment I.

The effects of photoperiod on germination of spores and initial development of gametophytes were tested using the following photoperiods: 0 (24 h darkness), 6, 12, 18 and 24 hours of light. The $\mathrm{pH}$ of the Meyer liquid medium and the temperature used for cultivation were chosen based on the results of the previous experiments. Three repetitions were prepared for each treatment, totaling 15 flasks. Germination and gametophytic development were assessed after seven, 30 and 60 days, using the methodology described for Experiment I.

\section{Abiotic conditions in the environment of occurrence of the donor plants: pH of the soil, temperature and photoperiod}

The $\mathrm{pH}$ was tested in samples of soil from the site where the plants from which spores had been collected occur. Samples from a depth of $20 \mathrm{~cm}$ had been taken at three points chosen at random next to individuals of $C$. phalerata. The $\mathrm{pH}$ tests employed the methodology described by Silva (2009). Temperature data for this environment were measured using a mobile weather station (Davis Vantage PRO 2 VP USB NS), located within the municipality of Caraá, $7.5 \mathrm{~km}$ (in a straight line) from the site where the individuals of C. phalerata occur (29 $44^{\prime} 15.88^{\prime \prime}$ '; 50 $21^{\circ} 34.52^{\prime \prime} \mathrm{W}, 375 \mathrm{~m}$ altitude). Data on photoperiod in the natural environment were obtained from Brazil's National Observatory for the municipality of Porto Alegre (ON 2015).

\section{Statistical analysis}

The Shapiro-Wilk test was used to test for the normality of data, which were assessed using the analysis of variance (ANOVA). Differences between means were analyzed by using the Duncan test with $5 \%$ probability. The statistical program employed was SPSS 22.

\section{Results}

\section{Establishment of ideal conditions for spore surface sterilization}

In Experiment I, treatments with 1.5 and $2 \% \mathrm{NaClO}$ and nystatin resulted in 90.33 and $91.67 \%$ of spores germinated, respectively, and were both significantly different from the treatment with $2 \% \mathrm{NaClO}$ and actidione, in which $82.33 \%$ of the spores had germinated after 30 days of cultivation. The treatment with $1.5 \% \mathrm{NaClO}$ and actidione resulted in an intermediate percentage of spores germinated (Fig. 1). Analysis of gametophytic development revealed a similar situation. The treatments with 1.5 and $2 \% \mathrm{NaClO}$ and nystatin resulted, respectively, in 72.67 and $77.33 \%$ of laminar gametophytes (the most advanced gametophytic stage observed in this experiment), significantly differing from treatments with actidione, to the extent that the treatment with $2 \% \mathrm{NaClO}$ and actidione exhibited just 
$8.67 \%$ of gametophytes at this stage (Fig. 1 ). The difference between the percentage of germinated spores and the percentage of laminar gametophytes are due to the existence of gametophytes at earlier stages of development, not recorded. Contamination by fungi was detected in all of the flasks from Experiment I.

All treatments tested in Experiment II were effective in terms of surface sterilization, since there was no contamination of the culture medium by fungi or bacteria. In terms of germination, it was observed that the treatment with $2.5 \% \mathrm{NaClO}$ for 15 min exhibited $88.10 \%$ of spores germinated and was significantly different from the treatment with $2 \% \mathrm{NaClO}$ for $25 \mathrm{~min}$ (83.10\%), whereas the treatment with $2 \% \mathrm{NaClO}$ for 20 min exhibited an intermediate value. With regard to the presence of laminar gametophytes, no significant differences were observed between treatments, but the highest percentage was observed in the treatment with $2.5 \% \mathrm{NaClO}$ for $15 \mathrm{~min}$ (Fig. 2).

\section{Assessment of the influence of abiotic conditions on spore germination and gametophyte development}

The $\mathrm{pH}$ of the culture medium influenced the germination of spores and development of gametophytes of $C$. phalerata. The first analysis was conducted after seven days of cultivation and it was observed that no spores had germinated in the $\mathrm{pH} 7$ treatment, whereas in all the other pHs from 18 to $25 \%$ of spores had germinated. The cultures with $\mathrm{pH}$ adjusted to 5 exhibited the highest percentage of germination, which was significantly different from the percentage germination in $\mathrm{pH} 6$ (Tab. 1).

After 30 days of cultivation, it was observed that treatments with $\mathrm{pH}$ adjusted to 4,5 and 6 exhibited, respectively, $70.33,75.00$ and $75.33 \%$ of spores germinated, significantly differing from $\mathrm{pH}$ 7. The medium adjusted to pH 6 exhibited $65 \%$ of laminar gametophytes and this value was significantly higher than in the other treatments. The cultures adjusted to $\mathrm{pH} 7$ continued to exhibit the lowest percentage of laminar gametophytes (Tab. 1). After 60 days of cultivation, the culture media adjusted to $\mathrm{pHs} 4$, 5 and 6 did not significantly differ from one another, but it was observed that $\mathrm{pH} 5$ had the highest percentage of germinated spores. The cultures with medium adjusted to $\mathrm{pH} 7$ continued to exhibit significantly lower proportions of germinated spores. The profiles of gametophytic development were similar to those for germination of spores at this point in the experiment. The culture media adjusted to $\mathrm{pH} 5$ and 6 exhibited 77.67 and $76.33 \%$ of laminar gametophytes and was significantly different from those at $\mathrm{pH} 4$ and 7 . At this time, from 7 to $9 \%$ of cordiform gametophytes could also be observed in media with $\mathrm{pH} 4$, 5 and 6 (Tab. 1).

The tests for the influence of temperature on the initial ontogenetic development of $C$. phalerata showed that the cultures maintained at 10 and $15{ }^{\circ} \mathrm{C}$ exhibited zero germination during the period of analysis. The other temperatures tested had different influences on germination

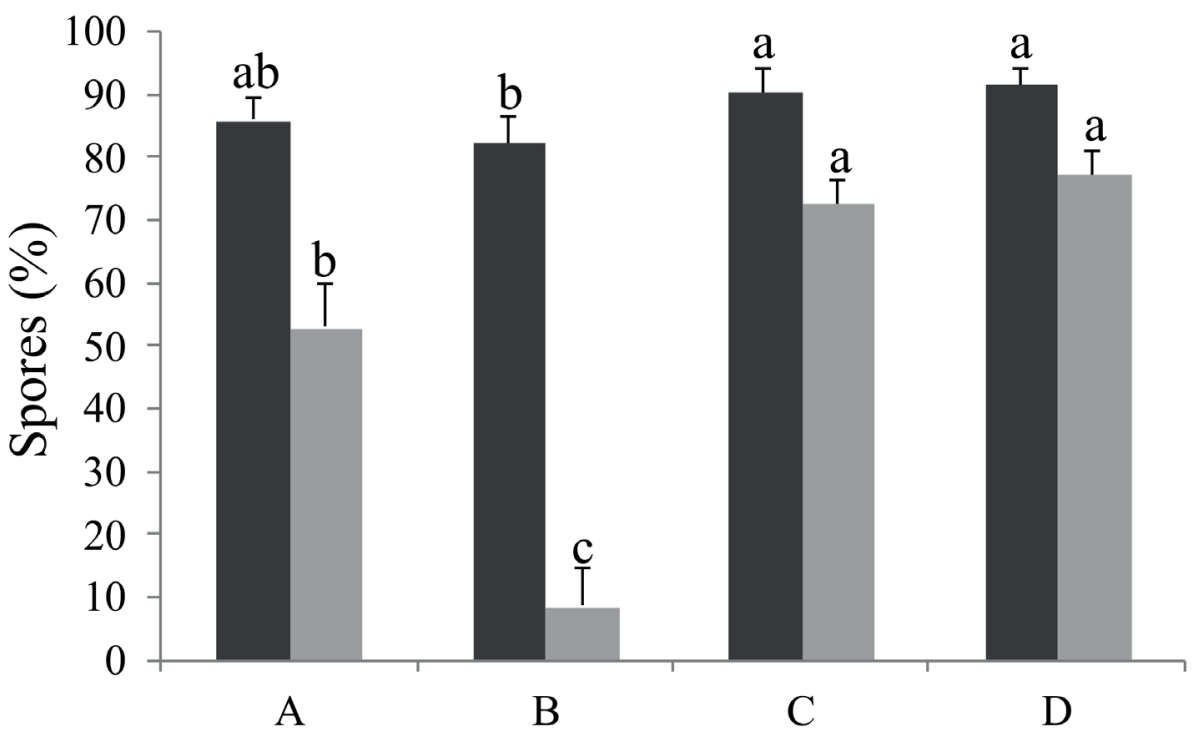

Figure 1. Influence of different concentrations of sodium hypochlorite $(\mathrm{NaClO})$ and addition of actidione or nystatin to the culture medium on the percentages (mean \pm standard deviation) of spores germinated and on gametophytic development of Cyathea phalerata after 30 days of cultivation. (A) $1.5 \% \mathrm{NaClO} /$ actidione; (B) $2 \% \mathrm{NaClO} /$ actidione; (C) $1.5 \% \mathrm{NaClO} /$ nystatin; (D) $2 \% \mathrm{NaClO} / \mathrm{nystatin}$. Same letters above columns of the same color indicate that data are not significantly different from each other, according to the Duncan test at $5 \%$ probability. Black columns indicate the total percentage of germinated spores; gray columns indicate the percentage of laminar spores. Bar = standard deviation. 


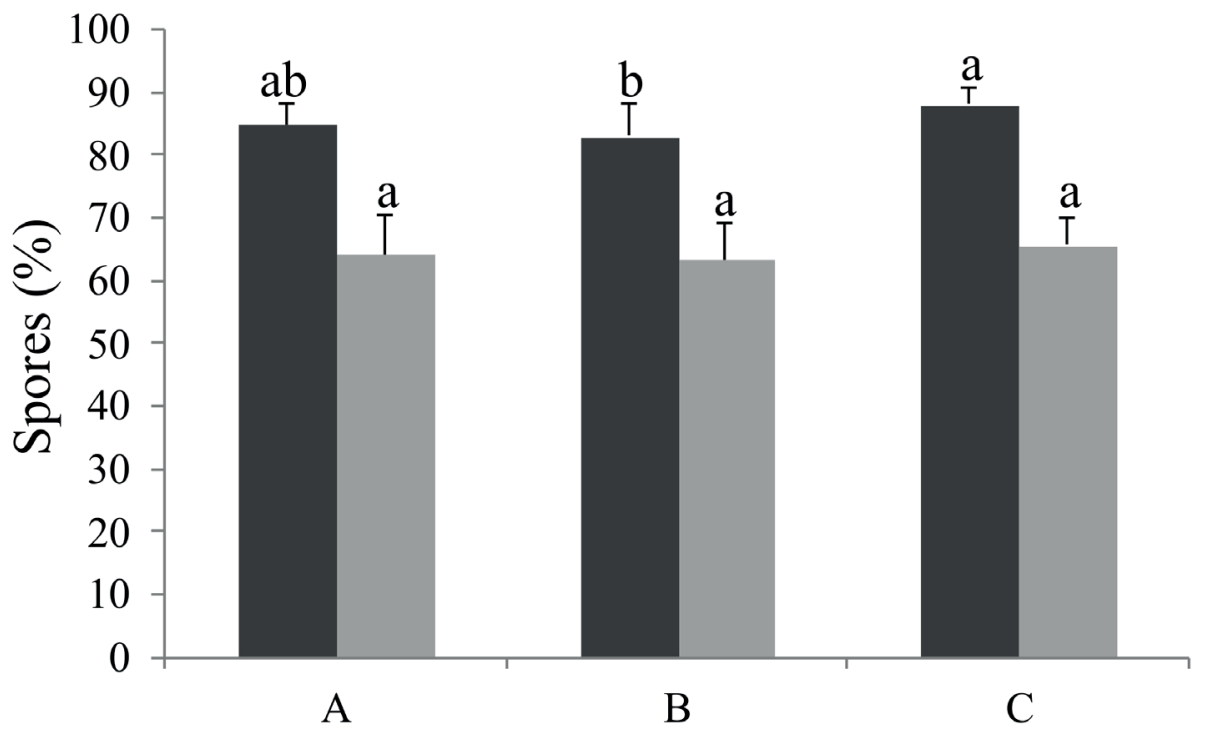

Figure 2. Influence of different concentrations of sodium hypochlorite $(\mathrm{NaClO})$ and exposure times on percentages (mean \pm standard deviation) of spores germinated and on gametophytic development of Cyathea phalerata after 30 days of cultivation. (A) $2 \% \mathrm{NaClO}$ for $20 \mathrm{~min} /$ nystatin; (B) $2 \% \mathrm{NaClO}$ for $25 \mathrm{~min} /$ nystatin; (C) $2.5 \% \mathrm{NaClO}$ for $15 \mathrm{~min} /$ nystatin. Same letters above columns of the same color indicate that data are not significantly different from each other, according to the Duncan test at $5 \%$ probability. Black columns indicate the total percentage of germinated spores; gray columns indicate the percentage of laminar spores. Bar $=$ standard deviation.

Table 1. Percentage (mean \pm standard deviation) germination and gametophytic development of Cyathea phalerata cultivated in culture media with different $\mathrm{pHs}$. Same letters in the line indicate that data are not significantly different from each other according to the Duncan test, at $5 \%$ probability. GS: germinated spores; LG: laminar gametophytes: CG: cordiform gametophytes.

\begin{tabular}{|c|c|c|c|c|c|c|c|}
\hline \multirow{2}{*}{ Days } & \multirow{2}{*}{ Stage } & \multicolumn{4}{|c|}{ pH } & \multirow[b]{2}{*}{$F$} & \multirow[b]{2}{*}{$\mathbf{p}$} \\
\hline & & 4 & 5 & 6 & 7 & & \\
\hline 7 & GS & $23.00 \pm 5.00 \mathrm{ab}$ & $25.33 \pm 2.08 \mathrm{a}$ & $18.33 \pm 3.21 \mathrm{~b}$ & $0.00 \pm 0.00 c$ & 39.91 & $<0.001$ \\
\hline \multirow[t]{2}{*}{30} & GS & $70.33 \pm 0.58 a$ & $75.00 \pm 2.65 \mathrm{a}$ & $75.33 \pm 3.21 \mathrm{a}$ & $25.33 \pm 4.62 \mathrm{~b}$ & 180.48 & $<0.001$ \\
\hline & LG & $50.33 \pm 6.03 \mathrm{~b}$ & $57.00 \pm 4.36 \mathrm{~b}$ & $65.00 \pm 2.65 \mathrm{a}$ & $6.67 \pm 0.58 c$ & 130.32 & $<0.001$ \\
\hline \multirow[t]{3}{*}{60} & GS & $84.33 \pm 3.05 a$ & $90.33 \pm 2.08 \mathrm{a}$ & $89.67 \pm 4.51 \mathrm{a}$ & $37.33 \pm 10.26 \mathrm{~b}$ & 56.14 & $<0.001$ \\
\hline & LG & $63.00 \pm 3.47 \mathrm{~b}$ & $77.67 \pm 1.15 \mathrm{a}$ & $76.33 \pm 5.51 \mathrm{a}$ & $31.00 \pm 5.57 c$ & 75.69 & $<0.001$ \\
\hline & CG & $9.67 \pm 3.78 \mathrm{a}$ & $9.67 \pm 2.31 \mathrm{a}$ & $7.67 \pm 2.08 \mathrm{a}$ & $0.00 \pm 0.00 \mathrm{~b}$ & 10.57 & 0.004 \\
\hline
\end{tabular}

and after seven days of cultivation the cultures maintained at $25^{\circ} \mathrm{C}$ exhibited $22 \%$ of spores germinated, significantly differing from the other treatments (Tab. 2).

After 30 days of cultivation, the cultures maintained at $25{ }^{\circ} \mathrm{C}$ exhibited $64.67 \%$ of spores germinated, which was a significantly superior percentage to those observed in the other treatments. The lowest germination percentage was observed in cultures maintained at $30^{\circ} \mathrm{C}$. The most advanced stage observed at this time was laminar gametophytes, and these were only observed in cultures maintained at temperatures from 20 to $30{ }^{\circ} \mathrm{C}$. However, just $3.67 \%$ of individuals were at this stage in the $30{ }^{\circ} \mathrm{C}$ treatment, whereas the $20^{\circ} \mathrm{C}$ cultures exhibited $20.33 \%$ and the $25^{\circ} \mathrm{C}$ treatments had $47.67 \%$ of laminar gametophytes, with significant differences between these treatments (Tab. 2).

After 60 days of cultivation, $83.33 \%$ of germinated spores were observed in the cultures maintained at $25^{\circ} \mathrm{C}$,
$62.67 \%$ were observed in cultures at $20^{\circ} \mathrm{C}$ and just $47.33 \%$ of spores maintained at $30{ }^{\circ} \mathrm{C}$ had germinated, which were significant different. Gametophytic development also exhibited significant difference between these three treatments (Tab. 2).

The $C$. phalerata spores were unable to germinate in the absence of light, indicating that the species is positively photoblastic. However, germination of spores and development of gametophytes were observed in all treatments exposed to light, irrespective of the exposure time or light intensity. After seven days, it was observed that $7 \%$ of the spores in cultures exposed to $12 \mathrm{~h}$ of light per day had germinated, significantly differing from treatments with other photoperiods (Tab. 3).

After 30 days of cultivation, the cultures exposed to a $12 \mathrm{~h}$ photoperiod still exhibited the highest germination percentage, differing significantly from the cultures with 6 
Table 2. Percentage (mean \pm standard deviation) germination and gametophytic development of Cyathea phalerata cultivated at different temperatures. Same letters in the line indicate that data are not significantly different from each other according to the Duncan test, at $5 \%$ probability. GS: germinated spores; LG: laminar gametophytes; CG: cordiform gametophytes.

\begin{tabular}{|c|c|c|c|c|c|c|c|c|}
\hline \multirow{2}{*}{ Days } & \multirow{2}{*}{ Stage } & \multicolumn{5}{|c|}{ Temperature } & \multirow{2}{*}{$\mathbf{F}$} & \multirow{2}{*}{$\mathbf{p}$} \\
\hline & & $10^{\circ} \mathrm{C}$ & $15^{\circ} \mathrm{C}$ & $20^{\circ} \mathrm{C}$ & $25^{\circ} \mathrm{C}$ & $30^{\circ} \mathrm{C}$ & & \\
\hline 7 & GS & $0.00 c$ & $0.00 c$ & $1.00 \pm 1.00 \mathrm{~b}$ & $22.00 \pm 2.45 \mathrm{a}$ & $12.33 \pm 3.78 b$ & 65.05 & $<0.001$ \\
\hline \multirow[t]{2}{*}{30} & GS & $0.00 \mathrm{~d}$ & $0.00 \mathrm{~d}$ & $50.00 \pm 4.36 \mathrm{~b}$ & $64.67 \pm 1.15 \mathrm{a}$ & $33.00 \pm 27.15 c$ & 282.05 & $<0.001$ \\
\hline & LG & $0.00 \mathrm{~d}$ & $0.00 \mathrm{~d}$ & $20.33 \pm 2.08 b$ & $47.67 \pm 2.08 \mathrm{a}$ & $3.67 \pm 2.08 c$ & 482.24 & $<0.001$ \\
\hline \multirow[t]{3}{*}{60} & GS & $0.00 \mathrm{~d}$ & $0.00 \mathrm{~d}$ & $62.67 \pm 2.08 \mathrm{~b}$ & $83.33 \pm 3.79 \mathrm{a}$ & $47.33 \pm 1.53 c$ & 1006.51 & $<0.001$ \\
\hline & LG & $0.00 \mathrm{~d}$ & $0.00 \mathrm{~d}$ & $34.67 \pm 1.53 \mathrm{~b}$ & $67.67 \pm 4.93 \mathrm{a}$ & $13.33 \pm 3.05 c$ & 341.93 & $<0.001$ \\
\hline & CG & $0.00 c$ & $0.00 c$ & $4.00 \pm 1.73 \mathrm{~b}$ & $8.00 \pm 1.73 \mathrm{a}$ & $0.00 \pm 0.00 c$ & 32.00 & $<0.001$ \\
\hline
\end{tabular}

Table 3. Percentage (mean \pm standard deviation) germination and gametophytic development of Cyathea phalerata cultivated with different photoperiods. Same letters in the line indicate that data are not significantly different from each other according to the Duncan test, at $5 \%$ probability. GS: germinated spores; LG: laminar gametophytes; CG: cordiform gametophytes.

\begin{tabular}{|c|c|c|c|c|c|c|c|c|}
\hline \multirow{2}{*}{ Days } & \multirow{2}{*}{ Stage } & \multicolumn{5}{|c|}{ Photoperiod } & \multirow{2}{*}{$\mathbf{F}$} & \multirow{2}{*}{$\mathbf{p}$} \\
\hline & & $\mathbf{O h}$ & $6 \mathrm{~h}$ & $12 \mathrm{~h}$ & $18 \mathrm{~h}$ & $24 \mathrm{~h}$ & & \\
\hline 7 & GS & $0.00 \pm 0.00 \mathrm{~b}$ & $1.33 \pm 1.53 \mathrm{~b}$ & $7.00 \pm 1.00 \mathrm{a}$ & $1.00 \pm 1.73 \mathrm{~b}$ & $0.67 \pm 1.15 \mathrm{~b}$ & 15.761 & $<0.001$ \\
\hline \multirow[t]{2}{*}{30} & GS & $0.00 \pm 0.00 \mathrm{~d}$ & $39.33 \pm 6.81 \mathrm{bc}$ & $53.67 \pm 7.51 \mathrm{a}$ & $47.00 \pm 1.73 \mathrm{ab}$ & $37.67 \pm 3.05 c$ & 56.801 & $<0.001$ \\
\hline & LG & $0.00 \pm 0.00 c$ & $32.33 \pm 7.09 \mathrm{a}$ & $31.67 \pm 2.08 \mathrm{a}$ & $28.33 \pm 3.05 \mathrm{a}$ & $20.67 \pm 1.15 b$ & 41.574 & $<0.001$ \\
\hline \multirow[t]{3}{*}{60} & GS & $0.00 \pm 0.00 \mathrm{~d}$ & $78.33 \pm 3.78 \mathrm{a}$ & $73.33 \pm 3.05 b$ & $80.67 \pm 1.52 \mathrm{a}$ & $66.00 \pm 3.00 c$ & 490.333 & $<0.001$ \\
\hline & LG & $0.00 \pm 0.00 c$ & $60.67 \pm 3.21 \mathrm{a}$ & $56.00 \pm 5.57 \mathrm{a}$ & $56.00 \pm 1.73 \mathrm{a}$ & $45.67 \pm 5.03 \mathrm{~b}$ & 134.785 & $<0.001$ \\
\hline & CG & $0.00 \pm 0.00 c$ & $14.33 \pm 0.58 \mathrm{a}$ & $15.67 \pm 3.21 \mathrm{a}$ & $15.00 \pm 1.00 \mathrm{a}$ & $8.67 \pm 3.21 b$ & 29.826 & $<0.001$ \\
\hline
\end{tabular}

and $24 \mathrm{~h}$ of light per day. Cultures with an $18 \mathrm{~h}$ photoperiod exhibited an intermediate germination percentage. The lowest proportion of laminar gametophytes was observed in cultures with a $24 \mathrm{~h}$ photoperiod, differing significantly from the percentages resulting from exposure to 6,12 and $18 \mathrm{~h}$ of light per day (Tab. 3).

The analysis of germination after 60 days of cultivation revealed that the 6 and $18 \mathrm{~h}$ photoperiod treatments had 78.33 and $80.67 \%$ of spores germinated, notably differing from the percentages in treatments exposed to $12 \mathrm{~h}$ and 24 $\mathrm{h}$ of light per day. The analysis of gametophytic development showed that cultures exposed to 6,12 and $18 \mathrm{~h}$ of light per day had from 56 to $60 \%$ of laminar gametophytes, which was significantly different from the values in the treatment with $24 \mathrm{~h}$ of light per day. A statistical difference was also detected in an analysis of the proportion of cordiform gametophytes, since the treatments with 6,12 and $18 \mathrm{~h}$ photoperiods had all approximately $15 \%$ of individuals at this stage, whereas the $24 \mathrm{~h}$ treatment had just $8.67 \%$ of cordiforms (Tab. 3).

\section{Abiotic conditions in the environment of occurrence of the donor plants: pH of the soil, temperature and photoperiod}

The soil analysis revealed that the $\mathrm{pH}$ at the site where the plants from which spores had been collected occur is acidic, since the mean $\mathrm{pH}$ recorded was 5.8. In this environment, the maximum temperature observed during 2014 was $24.6{ }^{\circ} \mathrm{C}$ and the minimum temperature was $15.6^{\circ} \mathrm{C}$ (Fig. 3). According to data from the National Observatory, the shortest mean photoperiod recorded in the Porto Alegre area in 2014 was 10.24 h of light, during the winter, and the longest photoperiod was $14.05 \mathrm{~h}$ of light in the summer (Fig. 3).

\section{Discussion}

The target for in vitro cultivation is to maintain cultures under conditions as close as possible to those in the natural environment. In view of this, it would be interesting to conduct the process without performing surface sterilization of the biological material, but after the spores have been sown they tend to become contaminated, preventing the assessment of gametophytic development. One example of this can be found in a study using Platycerium bifurcatum (Polypodiaceae) (Camloh 1999), in which the spores did not undergo surface sterilization and contamination of the cultures was observed within the first 10 days of in vitro cultivation. Spore sterilization can result in a reduction in their capacity for germination (Simabukuro et al. 1998; Cox et al. 2003), which is why an assessment of each species' tolerance is necessary. In the present study, germination of $C$. phalerata spores was not compromised by surface sterilization in sodium hypochlorite, remaining greater than $80 \%$ in both experiments, although the sterilization process was not entirely effective for the elimination of fungi in Experiment I. This high germination rate may be 


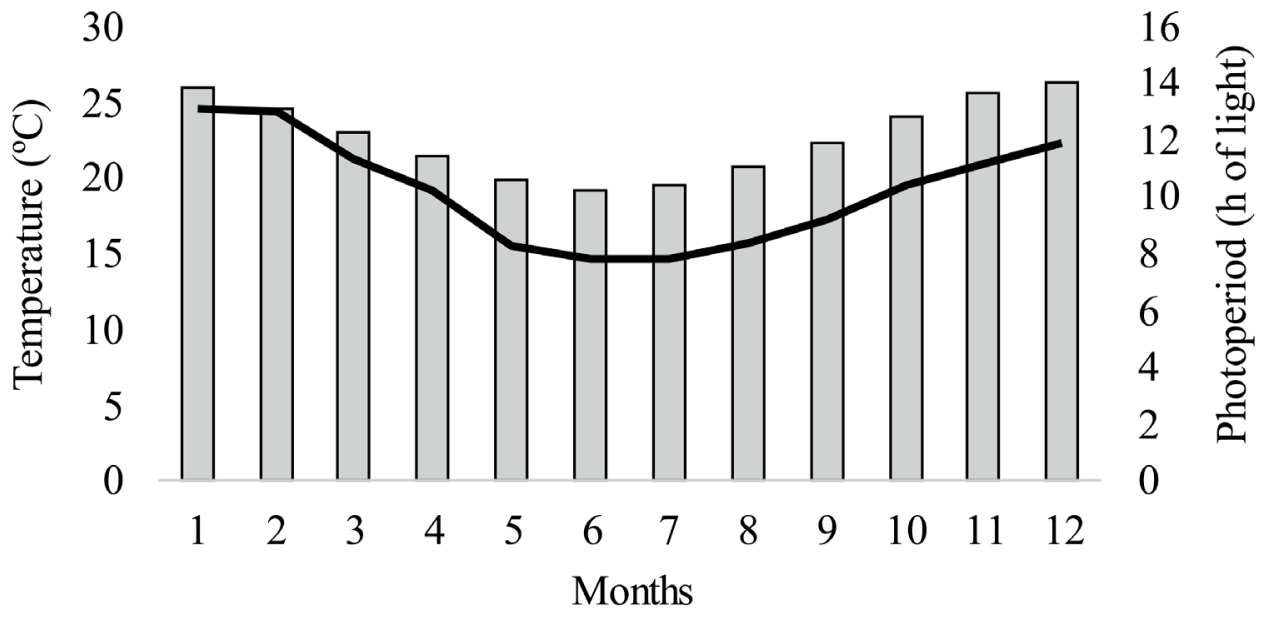

\section{$\square$ Photoperiod - Temperature}

Figure 3. Mean monthly temperatures and photoperiods for 2014, respectively, in the region of the study area and in the municipality of Porto Alegre, in Rio Grande do Sul, Brazil.

related to the fact that in addition to acting as agents of disinfection, hypochlorites can also be used to stimulate germination, because they have the capacity to stimulate $\alpha$-amylase activity, or, additionally, to aid with breaking dormancy (Kaneko \& Morohashi 2003).

Vargas \& Droste (2014) conducted tests to establish the ideal conditions for surface sterilization of $C$. atrovirens, observing $0.3 \%$ contamination in cultures, whether supplemented with nystatin or with actidione. However, at the end of the experiment, a lower proportion of laminar gametophytes was not observed in cultures with actidione, in contrast with what was observed for C. phalerata. Cycloheximide, the main active ingredient of actidione, is an antibiotic derived from a microbial source that inhibits protein synthesis in eukaryotic organisms (Wettstein et al. 1964). Inhibition is selective, with activity against most yeasts and fungi, but the substance is tolerated by the majority of bacteria (Wettstein et al. 1964; Schneider-Poetsch et al. 2010). Nystatin is a polyene antimicrobial produced by a bacterium and, due to its chemical characteristics, it can reduce contamination by fungi without affecting the development of gametophytes (Dyer 1983).

Cyathea phalerata spores that had been washed in $2 \%$ $\mathrm{NaClO}$ for 20 and $25 \mathrm{~min}$ and $2.5 \% \mathrm{NaClO}$ for $15 \mathrm{~min}$ did not subsequently become contaminated in a culture medium supplemented with nystatin, an antimicrobial agent that was previously considered effective for reducing contamination in cultures of Culcita macrocarpa (Culcitaceae), Dryopteris aemula, D. corleyi, D. guanchica (Dryopteridaceae) and Woodwardia radicans (Blechnaceae), ferns threatened with extinction in Spain (Quintanilla et al. 2002). Simabukuro et al. (1998) reduced, but did not eliminate, exogenous contamination of $C$. delgadii through the sterilization of spores with $0.5 \% \mathrm{NaClO}$ for $2 \mathrm{~min}$ and addition of nystatin. Brum \& Randi (2002) observed that the best method of decontamination with the highest percentage of germination for Rumohra adiantiformis (Dryopteridaceae) was using $15 \%$ of a commercial $\mathrm{NaClO}$ solution (containing $2 \%$ active chlorine) for 10 min plus supplementation of the culture medium with Benomil (Benlate). Sterilization of spores using $\mathrm{NaClO}$ combined with the addition of Benlate to the culture medium has been successfully employed for in vitro cultivation of fern species (Brum \& Randi 2002; Viviani \& Randi 2008; Santos et al. 2010). However, it has been illegal to sell this fungicide in Brazil since 2001.

The highest percentages of $C$. phalerata spore germination and greatest proportions of laminar gametophytes observed when media with acidic $\mathrm{pHs}$ were used may reflect the preferential conditions for the plants to establish themselves in their natural habitat. The level of acidity measured in the soil where the species grows naturally was equivalent to the $\mathrm{pH}$ values of the treatments that best promoted gametophytic development in vitro. This preference exhibited by $C$. phalerata is in agreement with findings showing that many fern species present greatest germination and development in substrates with acidic to neutral $\mathrm{pHs}$ (Miller 1968; Raghavan 1980).

Studies undertaken with two other species of the Cyathea genus that also occur in the state of Rio Grande do Sul, $C$. atrovirens (Rechenmacher et al. 2010) and C. corcovadensis (Medeiros et al. 2016), also reported significantly higher germination percentages and proportions of laminar gametophytes in cultures with pHs from 4 to 6.5 than in cultures at $\mathrm{pH}$ 7. Herbaceous fern species also exhibit elevated germination rates in acidic $\mathrm{pHs}$, including Ophioglossum palmatum (Ophioglossaceae) (Whittier \& Moyroud 1993), Cheilanthes feei (Pteridaceae) (Nondorf 
et al. 2003), Polypodium lepidopteris (Polypodiaceae) and Gleichenella pectinata (Gleicheniaceae) (Viviani \& Randi 2008; Santos et al. 2010). Notwithstanding, some species of ferns exhibit low germination percentages or are even incapable of germinating in highly acidic substrates (Hevly 1963), like Anemia mexicana and A. phyllitidis (Schizaeaceae) (Nester \& Coolbaugh 1986).

Similarly to C. phalerata, germination of other Cyatheaceae is higher at median temperatures. Cyathea corcovadensis spores kept at different temperatures ranging from 23 to $29^{\circ} \mathrm{C}$ exhibited germination percentages that did not significantly differ from each other, and the highest value (95\%) was observed at $23^{\circ} \mathrm{C}$. In contrast, at $32{ }^{\circ} \mathrm{C}$ only $5.7 \%$ of the spores germinated (Medeiros et al. 2016). Cyathea fulva, Nephelea mexicana, Trichipteris bicrenata and T. scabriuscula exhibited partially inhibited spore germination at temperatures above $25^{\circ} \mathrm{C}$ (Pérez-García \& Ribas 1982). The negative interference that high temperatures have on germination of the spores is possibly due to the inhibition of the synthesis of proteins involved in the spore germination process, as a result of the decoupling of far-red phytochrome (Haupt 1991). However, spores from C. atrovirens exhibited germination percentages from 84 to $99 \%$ at 20 to $32^{\circ} \mathrm{C}$ and even at $15^{\circ} \mathrm{C}, 43 \%$ of spores germinated, demonstrating the species' plasticity to the temperatures of the environments in which the species occurs (Marcon et al. 2015).

Similarly to the germination of spores, the development of gametophytes of the Cyatheaceae species is also stimulated at median temperatures. Medeiros et al. (2016) observed, after 31 days of cultivation, percentages of laminar and cordiform gametophytes of $C$. corcovadensis at $26{ }^{\circ} \mathrm{C}$ (62\% and $1 \%$, respectively), comparable to those for $C$. phalerata, indicating that this temperature stimulates the gametophytic development velocity of this species. Marcon et al. (2015) observed from 61 to $73 \%$ of $C$. atrovirens laminar gametophytes at different temperatures ranging from 20 to $29^{\circ} \mathrm{C}$, significantly differing from the results at $32{ }^{\circ} \mathrm{C}(1 \%)$ and at $15^{\circ} \mathrm{C}$, temperature at which there were no laminar gametophytes. At temperatures of 23 and $26^{\circ} \mathrm{C}$, the aforementioned authors observed $2 \%$ and $0.25 \%$ of cordiform gametophytes respectively after 28 days of cultivation.

Cyathea phalerata gametophytes exhibited the greatest development at $25^{\circ} \mathrm{C}$, with double the number of laminar and cordiform gametophytes at this temperature than at $20^{\circ} \mathrm{C}$. A tendency was observed for arborescent fern species that occur in the state of Rio Grande do Sul to produce spores during the hottest months with the longest days. Studies on the phenology of Dicksonia sellowiana (Schmitt et al. 2009), C. atrovirens (Schmitt \& Windisch 2012) and C. corcovadensis (Neumann et al. 2014) found that the production of fertile leaves was related to an increase in the temperature and photoperiod. The fertile leaves obtained from the natural environment in which $C$. phalerata occurs were collected during the months under these conditions.
The germination result observed at the temperature range tested contributes to explain the restricted occurrence of $C$. phalerata until the $30^{\circ} \mathrm{S}$ parallel of Rio Grande do Sul (Gonzatti et al. 2016). At further south latitudes, the reduction in precipitation and temperature, as well as the increase in cold days, associated with frost events (Waechter 1990), may be associated with the reduction in the germination capacity in the natural environment.

Cyathea phalerata is positively photoblastic, since its spores did not germinate in the dark, corroborating statements made by Miller (1968) and by Esteves \& Felippe (1985), who claim that few fern species are able to germinate in the absence of light. Four of the species of Cyatheaceae that occur in the state of Rio Grande do Sul were evaluated for this characteristic and all were found to be positively photoblastic (Marcondes-Ferreira \& Felippe 1984; Azevedo et al. 2008; Marcon et al. 2015; Medeiros et al. 2016). This need for light to initiate the germination process indicates that spores exposed on the surface of the ground can germinate, as described for $C$. atrovirens and Alsophila setosa (Cyatheaceae) (Azevedo et al. 2008).

All the $C$. phalerata cultures exposed to light exhibited germination and gametophytic development, irrespective of the number of hours, as similarly observed for $C$. corcovadensis (Medeiros et al. 2016) and C. atrovirens (Marcon et al. 2015). Notwithstanding, for all three of these Cyatheaceae species, the lowest means for germination of spores and for proportion of laminar gametophytes were observed in cultures exposed to light 24 hours per day, which may be because of a need for alternation between periods with and without light, as it happens in the natural environment. The photoperiod conditions in the natural habitat in southern Brazil coincide with the conditions in which the optimal values of germination and initial development of the species were recorded in the controlled environment.

Fern spores are dispersed to long distances by the wind (Esteves 2013). Nevertheless, the restricted occurrence of C. phalerata in Rio Grande do Sul may be related to the fact that spores cannot find an ideal combination of temperature, $\mathrm{pH}$ and photoperiod in the natural environment, such as those determined in the laboratory.

\section{Acknowledgements}

We thank the Universidade Feevale for providing infrastructure and financial support, the Coordenação de Aperfeiçoamento de Pessoal de Nível Superior (CAPES) for a Masters grant awarded to the first author and the Fundação de Amparo à Pesquisa do Estado do Rio Grande do Sul (FAPERGS) for a research grant awarded to the second author. 


\section{References}

Azevedo F, Droste A, Windisch P. 2008. Aspectos da germinação de esporos e desenvolvimento da fase gametofítica de Alsophila setosa Kaulf. e Cyathea atrovirens Langsd. \& Fisch.) Domin (Cyatheaceae). Pesquisas. Botânica 59: 223-236.

Brum FMR, Randi AM. 2002. High irradiance and temperature inhibit the germination of the spores in the fern Rumohra adiantiformis (Forst.) Ching (Dryopteridaceae). Revista Brasileira de Botânica 25: 391-396.

Camloh M. 1999. Spore age and sterilization affect germination and early gametophyte development of Platycerium bifurcatum. American Fern Journal 89: 124-132.

Cox J, Bhatia P, Ashwath N. 2003. In vitro spore germination of the fern Schizaea dichotoma. Scientia Horticulture 97: 369-378.

Dyer AF. 1979. The culture of fern gametophytes for experimental investigation. In: Dyer AF. (ed.) The experimental biology of ferns. London, Academic Press. p. 253-305.

Dyer AF. 1983. Fern gametophytes in culture. A simple system for studying plant development and reproduction. Journal of Biological Education 7: 23-39.

Esteves LM. 2013. Banco de esporos de samambaias e licófitas: uma revisão. Anuário do Instituto de Geociências 36: 72-79.

Esteves LM, Felippe GM. 1985. Fotossensibilidade de esporos de pteridófitas dos cerrados. Revista Brasileira de Botânica 8: 219-222.

Farar DR, Dassler C, Watkins Jr JE, Skelton C. 2008. Gametophyte ecology. In: Ranker TA, Haufler CH. (eds.) Biology and evolution of ferns and lycophytes. New York: Cambridge University Press. p. 222-256.

Fernandes I. 2003. Taxonomia dos representantes de Cyatheaceae do Nordeste Oriental do Brasil. Pesquisas. Botânica 54: 1-54.

Gonzatti F, Machado L, Windisch PG. 2016. Distribution patterns of ferns and lycophytes in the Coastal Region of the state of Rio Grande do Sul, Brazil. Acta Botanica Brasilica 30: 239-253.

Haupt W. 1991. Phytochrome-mediated fern-spore germination: inhibition by elevated temperatures. Photochemistry and Photobiology 52: 57-59.

Hevly RH. 1963. Adaptations of cheilanthoid ferns to desert environments. Journal of the Arizona-Nevada Academy of Science 2: 164-175.

Hiendlmayer R, Randi AM. 2007. Response of spores and young gametophytes of Cyathea delgadii Sternb. (Cyatheaceae) and Blechnum brasiliense Desv. (Blechnaceae) to different light levels. Acta Botanica Brasilica 21: 909-915.

Hort MA, Dalbó S, Brighente IMC, Pizzolatti MG, Pedrosa RC, Ribeiro-doVale RM. 2008. Antioxidant and hepatoprotective effects of Cyathea phalerata Mart. (Cyatheaceae). Basic \& Clinical Pharmacology \& Toxicology 103: 17-24

Kaneco K, Morohashi Y. 2003. Effect of sodium hypochlorite treatment on the development of $\alpha$-amylase activity in mung bean cotyledons. Plant Science 164: 287-292.

Lehnert M. 2006. The Cyatheaceae and Dicksoniaceae (Pteridophyta) of Bolivia. Brittonia 58: 229-244.

Marcon C, Silveira T, Bender D, Droste A. 2015. Germinação de esporos e desenvolvimento gametofítico de Cyathea atrovirens (Langsd. et Fisch.) Domin (Cyatheaceae) em diferentes temperaturas e fotoperíodos. Ambiência 11: 409-422.

Marcondes-Ferreira W, Felippe GM. 1984. Effects of light and temperature on the germination of spores of Cyathea delgadii. Revista Brasileira de Botânica 7: 53-56.

Medeiros LG, Marcon C, Silveira T, Schmitt JL, Droste A. 2016. Looking for the conservation and sustainable use of Cyathea corcovadensis (Raddi) Domin (Cyatheaceae): the influence of environmental factors on gametophytes. Brazilian Journal of Botany Online First. DOI 10.1007/s40415-016-0316-5.

Meyer BS, Anderson DB, Swanson CA. 1955. Laboratory plant physiology. New York, Van Nostrand.

Miller JH. 1968. Fern gametophytes as experimental material. Botanical Review 34: 361-440.

Nester JE, Coolbaugh RC. 1986. Factors influencing spore germination and early development in Anemia mexicana and A. phyllitidis. Plant Physiology 82: 230-235.
Neumann MK, Schneider PH, Schmitt JL. 2014. Phenology, caudex growth and age estimation of Cyathea corcovadensis (Raddi) Domin (Cyatheaceae) in a subtropical forest in southern Brazil. Acta Botanica Brasilica 28: 274-280.

Nondorf SL, Dooley MA, Palmieri M, Swatzell LJ. 2003. The effects of $\mathrm{pH}$, temperature, light intensity, light quality, and moisture levels on spore germination in Cheilanthes feei of Southeast Missouri. American Fern Journal 93: 56-69.

ON - Observatório Nacional. 〈http://www.on.br〉. 03 Jul. 2015.

Page CN. 1979. The diversity of ferns: an ecological perspective. In: Dyer AF. (ed.) The experimental biology of ferns. London, Academic Press. p. 10-56.

Peel MC, Finlayson BL, Mcmahon TA. 2007. Updated world map of the Köppen-Geiger climate classification. Hydrology and Earth System Sciences 11: 1633-1644.

Pérez-García B, Riba R. 1982. Germinación de esporas de Cyatheaceae bajo diversas temperaturas. Biotropica 14: 281-287.

Petersen RL. 1985. Towards an appreciation of fern edaphic niche requirements. In: Dyer AF, Page CN. (eds.). Biology of Pteridophytes. Edinburgh: The Royal Society of Edinburgh. p. 93-103.

Quintanilla LG, Amigo J, Pangua E, Pajaron S. 2002. Effect of storage method on spore viability in five globally threatened fern species. Annals of Botany 90: 461-467.

Raghavan V. 1980. Cytology, physiology, and biochemistry of germination of fern spores. International Review of Cytology 62: 69-118.

Ranal MA. 1999. Effects of temperature on spore germination in some fern species from semideciduous mesophytic Forest. American Fern Journal 89: 149-158.

Rechenmacher C, Schmitt JL, Droste A. 2010. Spore germination and gametophyte development of Cyathea atrovirens (Langsd. \& Fisch.) Domin (Cyatheaceae) under different $\mathrm{pH}$ conditions. Brazilian Journal of Biology 70: 1155-1160.

Rio Grande do Sul. 2014. Decreto n 52.109, de 01 de dezembro de 2014. Declara as espécies da flora nativa ameaçadas de extinção no Estado do Rio Grande do Sul. Lex-Diario Oficial do Rio Grande do Sul, ano LXXII, n. 233, 2-11.

Rocha-Uriartt L, Cassanego MBB, Becker DFP, Droste A, Schmitt JL 2015. Diagnóstico ambiental de mata ciliar: uma análise integrada de parâmetros botânicos, meteorológicos e da genotoxicidade do ar atmosférico. Revista Brasileira de Ciências Ambientais 35: 102-115.

Santos EPG, Lehmann DRM, Santos M, Randi AM. 2010. Spore germination of Gleichenella pectinata (Willd.) Ching (Polypodiopsida-Gleicheniaceae) at different temperatures, levels of light and $\mathrm{pH}$. Brazilian Archives of Biology and Technology 53: 1309-1318.

Schmitt JL, Schneider PH, Windisch PG. 2009. Crescimento do cáudice e fenologia de Dicksonia sellowiana Hook. (Dicksoniaceae) no sul do Brasil. Acta Botanica Brasilica 23: 282-291.

Schmitt JL, Windisch PG. 2005. Aspectos ecológicos de Alsophila setosa Kaulf. (Cyatheaceae, Pteridophyta) no Rio Grande do Sul, Brasil. Acta Botanica Brasilica 19: 859-865.

Schmitt JL, Windisch PG. 2010. Biodiversity and spatial distribution of epiphytic ferns on Alsophila setosa Kaulf. (Cyatheaceae) caudices in Rio Grande do Sul, Brazil. Brazilian Journal of Biology 70: 521-528.

Schmitt JL, Windisch PG. 2012. Caudex growth and phenology of Cyathea atrovirens (Langsd. \& Fisch.) Domin (Cyatheaceae) in secondary forest, southern Brazil. Brazilian Journal of Biology 72: 397-405.

Schneider PH, Schmitt JL. 2011. Composition, community structure and vertical distribution of epiphytic ferns on Alsophila setosa Kaulf., in a Semideciduous Seasonal Forest, Morro Reuter, RS, Brazil. Acta Botanica Brasilica 25: 557-565.

Schneider-Poetsch T, Ju J, Eyler DE, et al. 2010. Inhibition of eukaryotic translation elongation by cycloheximide and lactimidomycin. Nature Chemical Biology 6: 209-217.

Silva FC. 2009. Manual de análises químicas de solos, plantas e fertilizantes. 2nd. edn. Brasília, Embrapa.

Silveira T, Marcon C, Droste A. 2013. Germinação de esporos armazenados a frio e desenvolvimento gametofítico in vitro de Cyathea atrovirens (Langd. \& Fisch. Domin (Cyatheaceae) na presença de antibióticos. Revista Jovens Pesquisadores 3: 23-33. 


\section{Abiotic environmental conditions for germination and development of gametophytes of Cyathea phalerata Mart. (Cyatheaceae)}

Simabukuro EA, Dyer AF, Felippe GM. 1998. The effect of sterilization and storage conditions on the viability of the spores of Cyathea delgadii Sternb. American Fern Journal 88: 72-80.

Vargas IB, Droste A. 2014. In vitro propagation of Cyathea atrovirens (Cyatheaceae): spore storage and sterilization conditions. Revista de Biología Tropical 62: 299-308.

Viviani D, Randi AM. 2008. Effects of pH, temperature and light on spore germination and growth analysis of young sporophytes of Polypodium lepidopteris (Pteridophyta, Polypodiaceae). Rodriguésia 59: 751-760.

Waechter JL. 1990. Comunidades vegetais das restingas do Rio Grande do Sul. In: Anais do II Simpósio de Ecossistemas da Costa Sul e Sudeste
Brasileira. Vol. 3. Águas de Lindóia. p. 228-248.

Wettstein FO, Noll H, Penman S. 1964. Effect of cycloheximide on ribosomal aggregates engaged in protein synthesis in vitro. Biochimica et Biophysica Acta 87: 523-525.

Whittier DP, Moyroud R. 1993. The promotion of spore germination and gametophyte development in Ophioglossum palmatum by low $\mathrm{pH}$. American Fern Journal 83: 41-46.

Windisch PG, Santiago ACP. 2015. Cyatheaceae. In: Lista de espécies da flora do Brasil. Jardim Botânico do Rio de Janeiro. http://floradobrasil. jbrj.gov.br/jabot/floradobrasil/FB90850. 15 May 2015. 